\title{
Inhibition activity of a disulfide-stabilized diabody against basic fibroblast growth factor in lung cancer
}

\author{
Yaxiong $\mathrm{Cai}^{1, *}$, Shuange Yao ${ }^{1, *}$, Jiangchuan Zhong ${ }^{1, *}$, Jinxia Zhang ${ }^{1}$, Haowu Jiang ${ }^{1}$, \\ Yanrui Deng ${ }^{1}$, Ning Deng ${ }^{1}$ \\ ${ }^{1}$ Guangdong Province Key Laboratory of Molecular Immunology and Antibody Engineering, College of Bioscience and \\ Technology in Jinan University, Guangzhou, China \\ *These authors have contributed equally to this work \\ Correspondence to: Ning Deng, email: tdengn@jnu.edu.cn \\ Keywords: ds-diabody, bFGF, lung cancer, angiogenesis, lymphangiogenesis \\ Received: July 29, 2016 Accepted: January 23, 2017 Published: February 21, 2017
}

\section{ABSTRACT}

The over-expression of basic fibroblast growth factor (bFGF) plays a crucial role in the development, invasion and metastasis of lung cancer. Therefore, neutralizing antibodies against bFGF may inhibit the growth of lung cancer. In this study, a Disulfide-stabilized diabody (ds-Diabody) against bFGF was constructed by sitedirected mutation and overlap extension PCR (SOE-PCR) at the position of VH44 and VL100 in the SCFv. The ds-Diabody was constructed and expressed in Pichia pastoris. We found that the ds-Diabody against bFGF could efficiently suppress the proliferation, migration and invasion of human lung cancer A549 cells in vitro. Moreover, in A549 cells, the ds-Diabody against bFGF could inhibit bFGF-induced activation of downstream signaling regulators, such as phospho-Akt and phosphoMAPK. In the nude mouse xenograft model of lung cancer, the ds-Diabody against bFGF could significantly inhibit tumor growth and decrease the densities of microvessels and lymphatic vessels in tumor tissue. Our data indicate that the ds-Diabody against bFGF could effectively suppress the lung cancer growth through blockade of bFGF signaling pathway and inhibition of tumor angiogenesis, which may make it a potential therapeutic candidate antibody drug for human lung cancer therapy.

\section{INTRODUCTION}

Basic fibroblast growth factor (bFGF) is a pleiotropic growth factor. One of the most important functions of $\mathrm{bFGF}$ is to promote endothelial cell proliferation and promote angiogenesis by the physical organization of endothelial cells into tube-like structures [1-3]. bFGF is overexpressed in malignant tumors [4-7]. The binding of bFGF and its receptor (FGFR) may activate the signaling pathways of MAPKs/ERKs and PI3K/AKT, which is correlated with tumor growth, migration, angiogenesis and lymphangiogenesis $[4,5]$. Therefore, blocking bFGF/ FGFR activity with antibodies might be a good therapeutic strategy for tumor patients [8].

The anti-bFGF murine monoclonal antibodies (mAbs) have been reported to have anti-tumor effect on chondrosarcoma, glioma, Lewis lung carcinoma and melanoma [9-12]. Li proved that traditional anti-bFGF murine mAbs display remarkable anti-tumor effect on B16 melanoma in vivo and in vitro [12]. However, traditional murine mAbs could induce human anti-mouse antibody (HAMA) response and interfere with the therapeutic effect [13-15]. It is very important to construct human antibodies to avoid HAMA reaction. Tao has prepared a full-length human antibody against bFGF, which could remarkably inhibit the growth of melanoma in vitro and in vivo [16].

Small molecule antibodies get more and more attention for its good tissue penetration and low immunogenicity. They may have a potential application in target therapy of human diseases [17]. Diabody is one of the small molecule antibodies, which is a non-covalently associated bivalent molecule, created from scFv by shortening the polypeptide linker between the VH and VL domains [18]. The diabody was non-covalently associated and the linker may interfere with the antigen binding, which may result in lower affinity and unstable [19]. Introduction of disulphide bond in the framework of VH and VL domains could stabilize the diabody and keep the affinity [17, 20-22]. 
In this study, we mainly reported the construction of ds-Diabody and the inhibition effect and the potential mechanisms of the human disulfide-stabilized diabody against bFGF on the growth of human lung cancer A549 cells in vitro and in vivo.

\section{RESULTS}

\section{Expression and purification of the ds-Diabody against bFGF}

The high affinity human antibodies of $\mathrm{scFv}$ against bFGF were selected from a phage display library [16]. The human disulfide-stabilized diabody against bFGF (dsDiabody) gene fragment was constructed by site-directed mutation and overlap extension (SOE-PCR) at the VH44 and VL100 position of the scFv (Figure 1). The ds- Diabody gene fragment was constructed into the yeast expression vector $\mathrm{pPICZ} \alpha \mathrm{A}$ and the recombinant plasmid pPICZ $\alpha \mathrm{A}-\mathrm{ds}$ Diabody was transformed into Pichia pasporis strain GS115. The ds-Diabody against bFGF could be high level expressed in yeast. The yield of recombinant ds-Diabody against bFGF could reach $30-50 \mathrm{mg} / \mathrm{L}$ in cell culture. The result of western-blot showed that the ds-Diabody against bFGF was specific appeared at the molecular weight of approximately $35 \mathrm{kDa}$ under reducing condition and $70 \mathrm{kDa}$ under nonreducing condition (Figure $2 b$ ).
The ds-Diabody against bFGF was secretion expressed in the supernatant of recombinant yeast and purified by Ni Sepharose ${ }^{\mathrm{TM}} 6$ affinity chromatography and anion-exchange chromatography. The high purity of recombinant ds-Diabody against bFGF was obtained and the purity of it is above $95 \%$ (Figure $2 \mathrm{a}$ ).

\section{Antigen binding activity of the ds-Diabody against bFGF}

The antigen binding activity of the ds-Diabody against bFGF was analyzed by indirect ELISA. When the concentration of the antibodies was $0.332 \mu \mathrm{g} / \mathrm{mL}$, the value of $\mathrm{OD}_{450 \mathrm{~nm}}$ of the ds-Diabody could reached about 1.0 , while the value of $\mathrm{OD}_{450 \mathrm{~nm}}$ of the full-length human antibody was just under 0.1 . The results showed that the ds-Diabody against bFGF could specifically bind to bFGF and the formation of disulphide bonds in the ds-Diabody did not influence its antigen binding activity (Figure 3 ).

\section{Proliferation inhibition of A549 cells by the ds-Diabody against bFGF}

The proliferation inhibition assay of A549 cells was conducted by CCK-8 kit. The results of cell proliferation inhibition assay showed that the cell viability was decreased with the increasing of the ds-

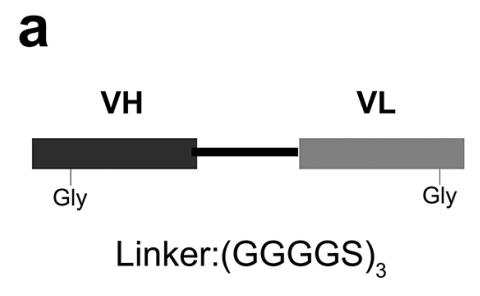

b

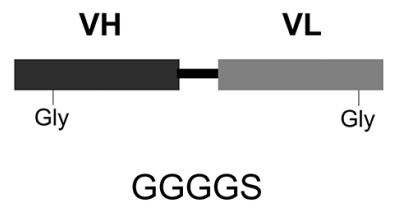

GGGGS
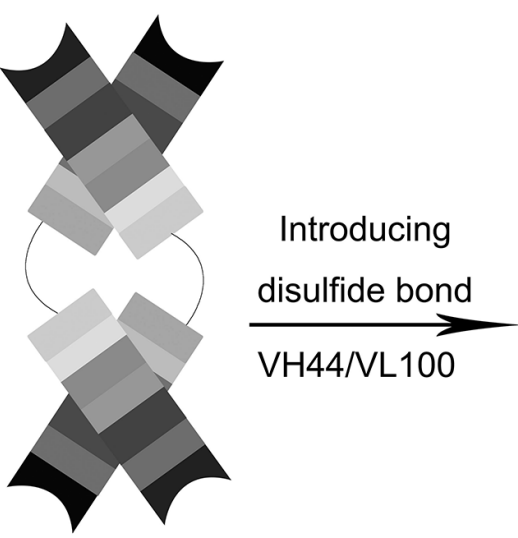

Diabody
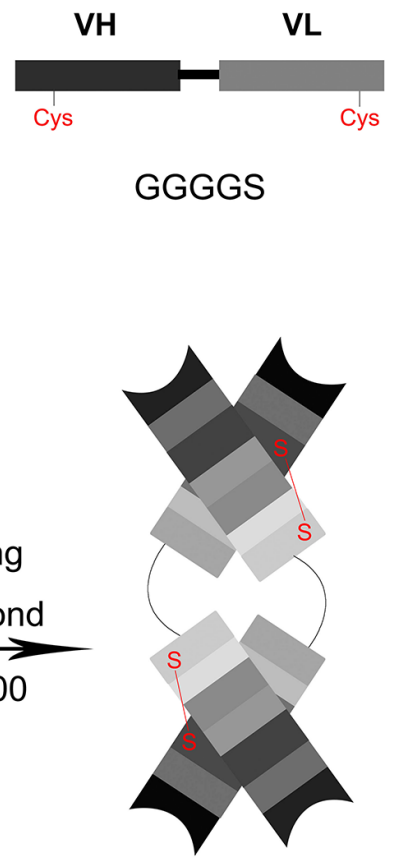

ds-Diabody

Figure 1: Construction of the ds-Diabody against bFGF. a. The ds-Diabody against bFGF was constructed by introducing disulfide bonds between VL and VH. b. Schematic representation of the construction of ds-Diabody against bFGF. 
Diaboy against bFGF. When the concentration of the ds-Diabody was $6.25,12.5,25,50$ and $100 \mu \mathrm{g} / \mathrm{mL}$, the cell proliferation inhibition rate was about $19.23 \%$, $28.59 \%, 31.88 \%, 37.35 \%$ and $40.94 \%$ respectively. The results indicated that the ds-Diaboy could inhibit the proliferation of human lung cancer A549 cells in a dose-dependent manner (Figure 4). The positive control of full-length human IgG against bFGF showed similarly inhibitory effect on the proliferation of A549 cells and the irrelevant IgG showed no inhibitory effect (Figure 4).

\section{Blocking of bFGF-triggered phosphorylation of Akt and MAPK by the ds-Diabody against bFGF}

The starved A549 cells were treated with different concentrations of ds-Diabody together with bFGF. The cells were lysed and the proteins in the lysates was separated with SDS-PAGE and assayed with western-blot. The western-blot results showed that the phosphorylation of Akt and MAPK could be activated by bFGF in A549 cells, and the ds-Diabody agasint bFGF could effectively block the phosphorylation activation of Akt and MAPK in a dose-dependent manner (Figure 5). The results revealed

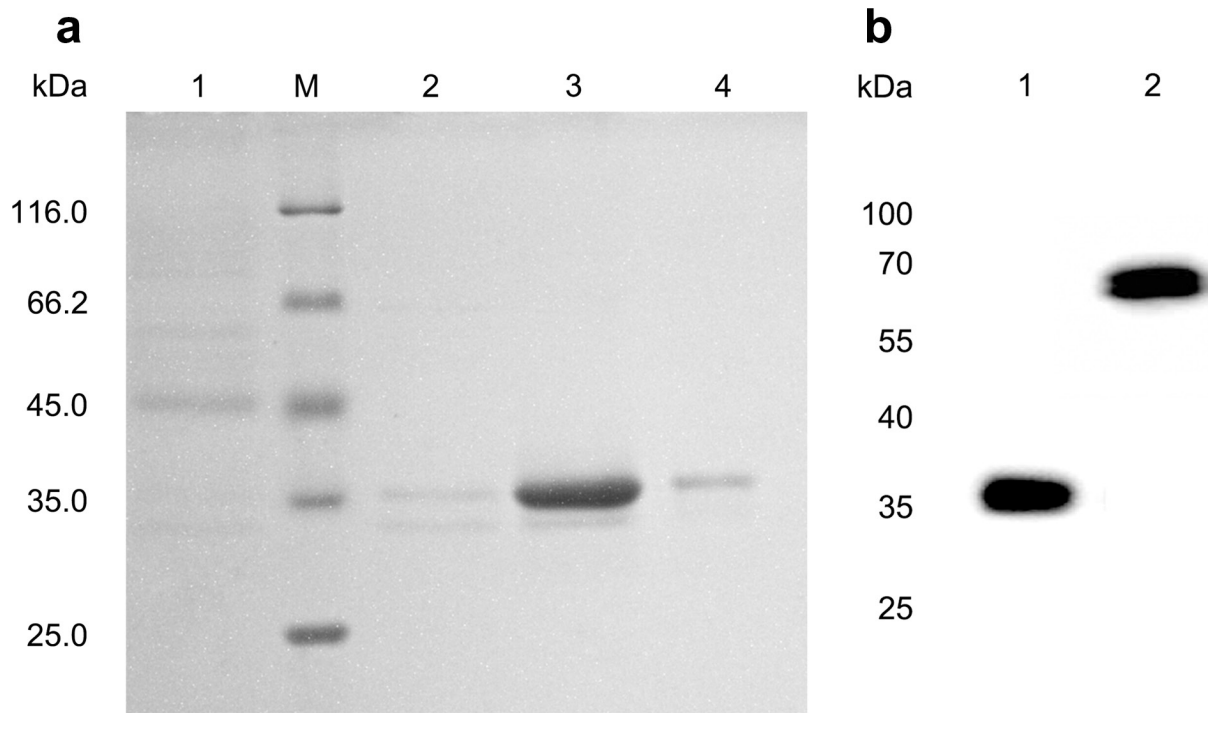

Figure 2: Purification and identification of the ds-Diabody against bFGF by SDS-PAGE and western-blot. a. SDS-PAGE of ds-Diabody against bFGF. Lane M: Protein molecular weight marker; Lane 1: Proteins from culture supernatant; Lane 2: Other proteins; Lane 3: Fractions obtained by Ni Sepharose affinity chromatography and anion-exchange chromatography; Lane 4: Other proteins. b. Western-blot assay of ds-Diabody against bFGF. Lane 1: Western blot assay of the ds-Diabody against bFGF under reducing condition; Lane 2: Western blot assay of the ds-Diabody against bFGF under non-reducing condition.

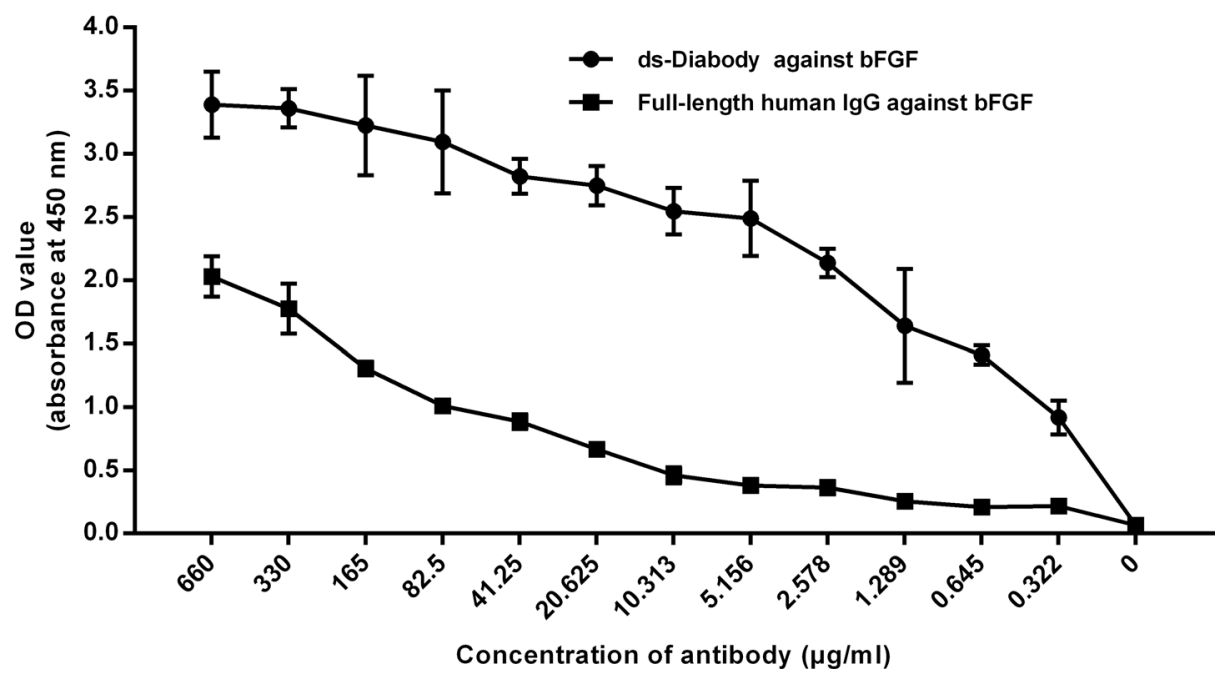

Figure 3: Antigen binding activity of the ds-Diabody and full-length human antibody against bFGF were assayed by indirect ELISA. 


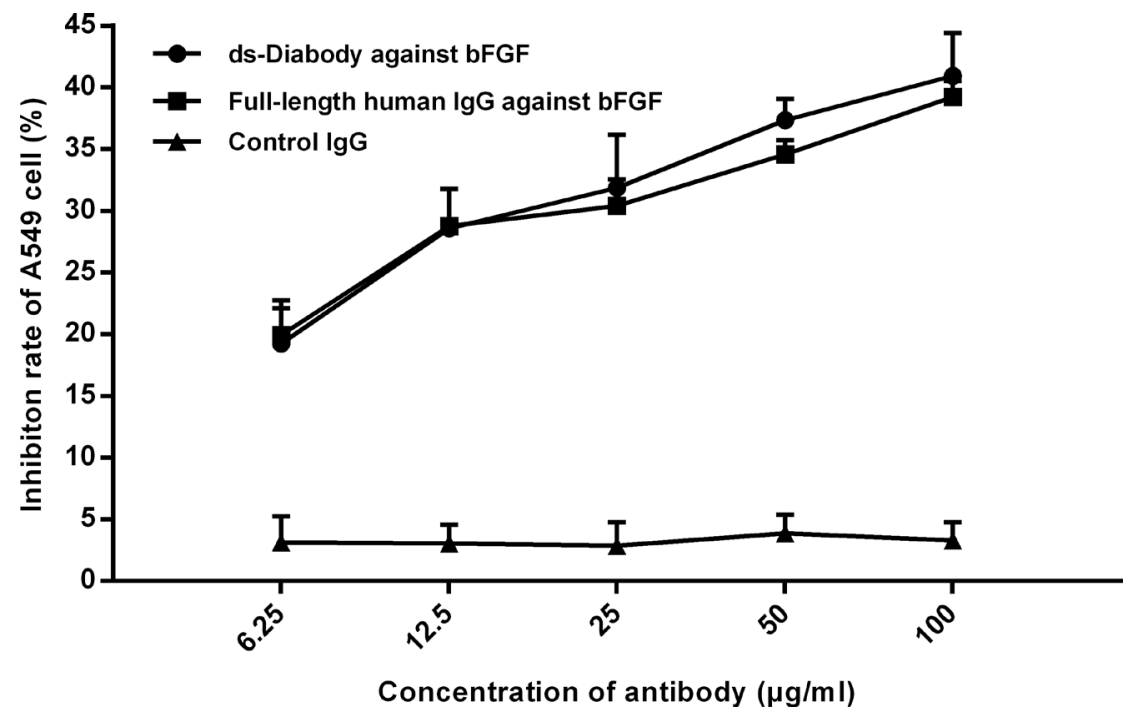

Figure 4: Proliferation inhibition effects of the ds-Diabody against bFGF on lung cancer cells. The lung cancer A549 cells $\left(2 \times 10^{3}\right.$ cells/well) were transferred to 96 -well plates and treated with $15 \mathrm{ng} / \mathrm{mL} \mathrm{bFGF}$ plus ds-Diabody at serially diluted concentrations. The results of CCK-8 showed that ds-Diabody against bFGF could inhibit the proliferation of lung cancer cells in dose dependent. The data were represented as the mean $\pm \mathrm{SD}$ of three independent experiments performed in triplicate.

a
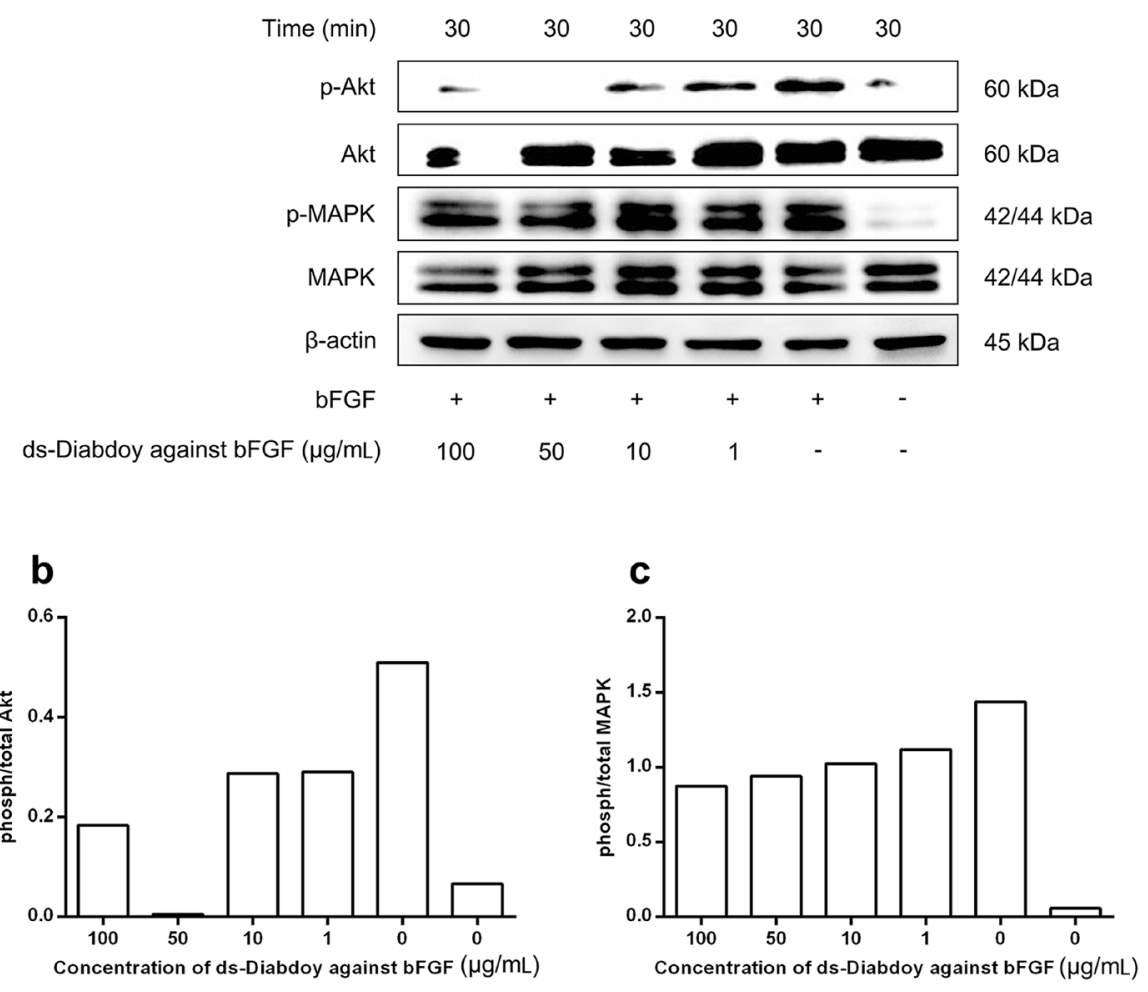

Figure 5: Western-blot assays of Akt and MAPK phosphorylation in lung cancer cells treated with the ds-Diabody against bFGF. The A549 cells $\left(2 \times 10^{5}\right.$ cells/well $)$ transferred in 6-well plates were serum-starved cultured and treated with $15 \mathrm{ng} / \mathrm{mL}$ bFGF and serially concentrations of the ds-Diabody and incubated for $30 \mathrm{~min}$. The cell lysates were collected and transferred in PVDF membrane for western-blot assay. The primary antibodies were anti-MAPK, anti-p-MAPK, anti-Akt and anti-p-Akt. The $\beta$-actin was served as the reference control. a. Akt and MAPK phosphorylation of human lung cancer A549 cells treated by various concentrations of ds-Diabody against bFGF (1-100 $\mu \mathrm{g} / \mathrm{mL})$ for $30 \mathrm{~min}$. b. Quantitative analysis of phosphorylated/total Akt. c. Quantitative analysis of phosphorylated/total MAPK. 
a

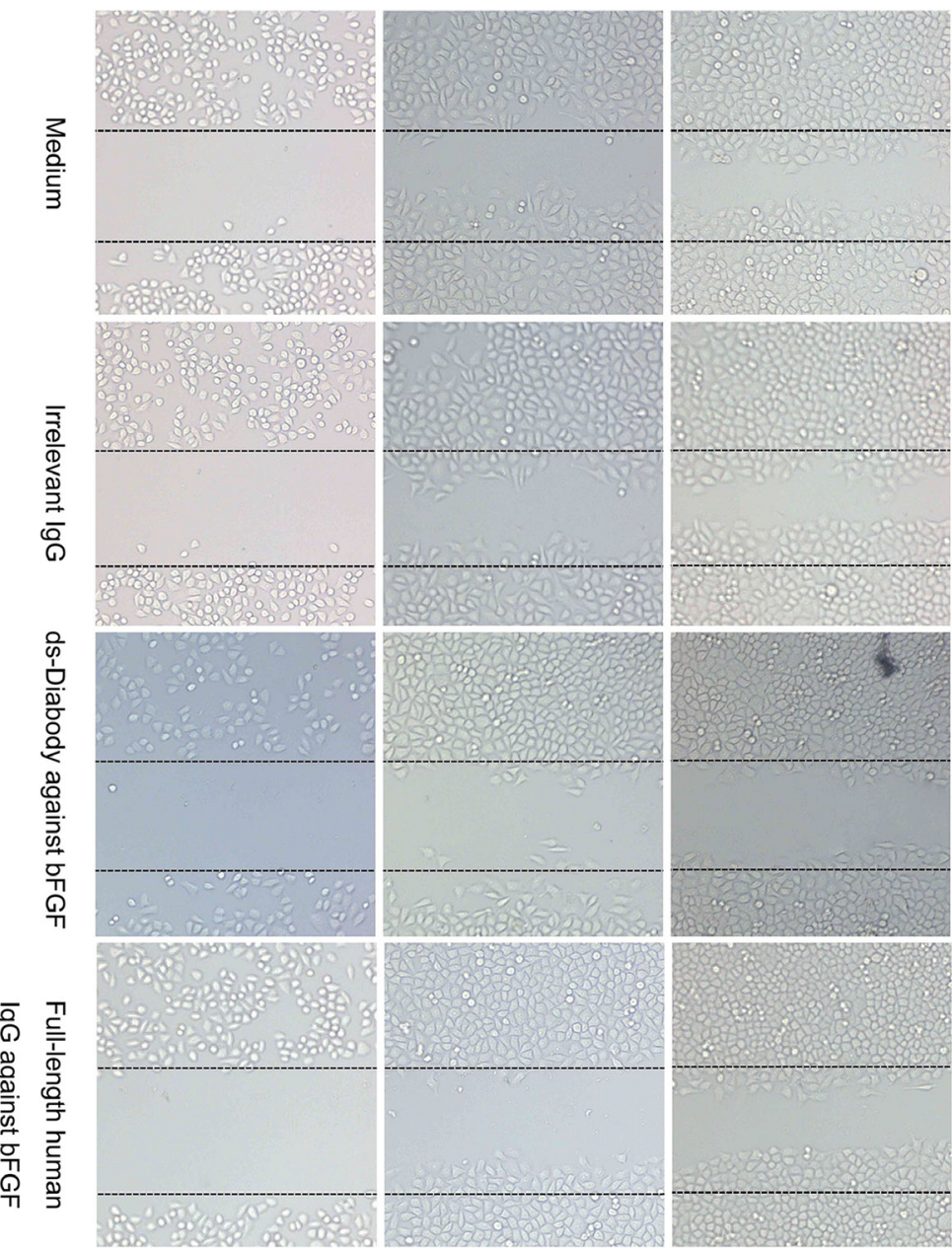

$24 \mathrm{~h}$

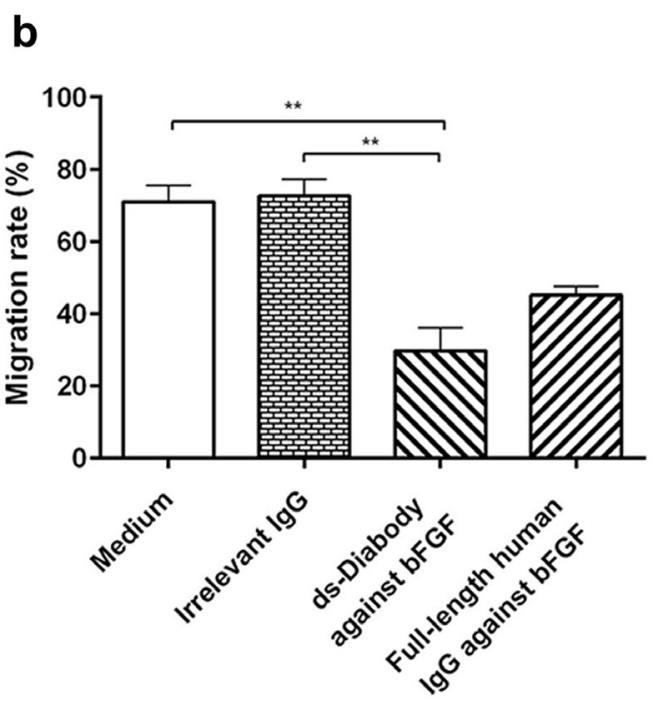

Figure 6: The migration inhibition of A549 cells by ds-Diabody against bFGF. a. The migration of A549 cells in different conditions at different times. b. The quantitative analysis of the migration rate of different groups. The results indicated that the ds-Diabody against bFGF could significantly inhibit the migration of A549 cells when compared with the Irrelevant IgG group $\left(* \mathrm{P}<0.05,{ }^{*} \mathrm{P}<0.01\right)$.
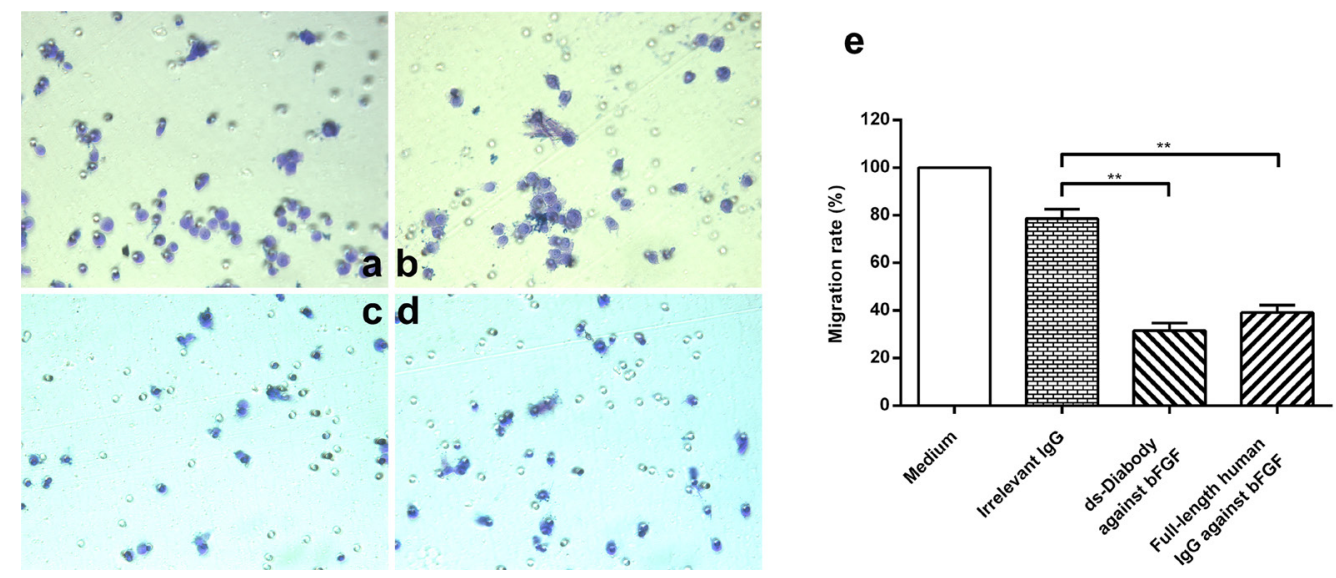

Figure 7: The invasion inhibitory of A549 cells by the ds-Diabody against bFGF. The cells were cultured in serum-free medium containing $15 \mathrm{ng} / \mathrm{mL}$ bFGF in the upper chamber and were chemo-attracted by the $10 \%$ serum in the lower chamber. The invasion cells migrated into the lower side were stained by crystal violet and imaged with a computerized imaging system. a. A549 cells were treated with DMEM serum-free medium. b. A549 cells were treated with the irrelevant IgG. c. A549 cells were treated with the ds-Diabody against bFGF. d. A549 cells were treated with the full-length human antibody against bFGF. e. The quantitative analysis of A549 invasion. The number of cells observed from serum-free DMEM medium group was set as 100 . The data were represented as the means $\pm \mathrm{SD}$. ${ }^{*} \mathrm{P}<0.05 ; * * \mathrm{P}<0.01$. 
that the ds-Diabody against bFGF could effectively suppress the proliferation of A549 cells by blocking the signal pathways of Akt and MAPK.

\section{Migration inhibition of A549 cells by ds-Diabody against bFGF}

The human lung cancer A549 cell was a kind of tumor cell with high migration capability [23]. When subjected to scratches, the A549 cells could migrate quickly to the blank area of scratch and repair the scratches. The migration rate of A549 cells after scratch treatment for $24 \mathrm{~h}$ in groups of the ds-Diabody against bFGF, the full-length human IgG against bFGF, the irrelevant $\mathrm{IgG}$ and medium alone were $29.72 \%, 45.24 \%$, $72.59 \%$ and $71.03 \%$ respectively (Figure 6). The results of scratch assay indicated that the ds-Diabody against bFGF could significantly inhibit the migration of A549 cells in vitro.

\section{Invasion inhibition of A549 cells by the ds-Diabody against bFGF}

The invasion assay of A549 cells was conducted in a transwell with matrigel. The A549 cells $\left(5 \times 10^{4}\right.$ cells/well $)$ were plated into the transwell with a layer of matrigel. The cells were serum-starved cultured to minimize any interference of serum growth factors, and stimulated with $15 \mathrm{ng} / \mathrm{mL} \mathrm{bFGF}$ and $100 \mu \mathrm{g} / \mathrm{mL}$ ds-Diabody against bFGF for $16 \mathrm{~h}$. In the upper chamber, the cells were cultured with serum-free medium containing $15 \mathrm{ng} / \mathrm{mL} \mathrm{bFGF}$ and the lower chamber were the medium with $10 \%$ serum. The a

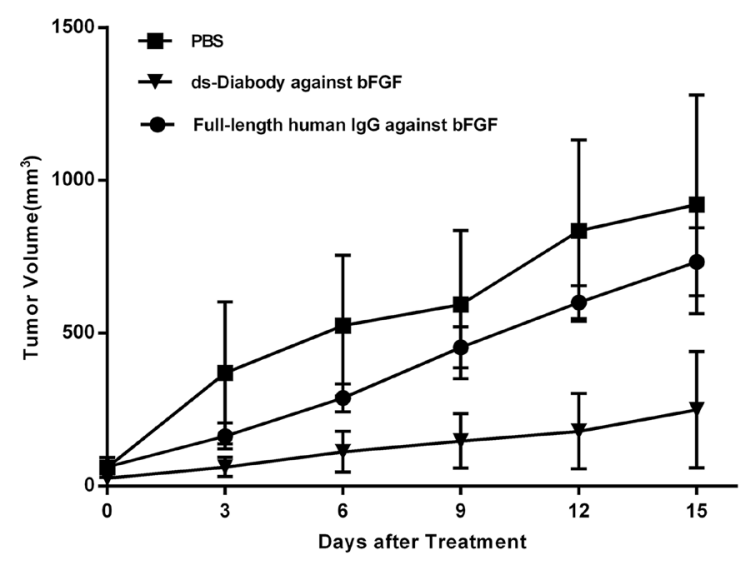

C

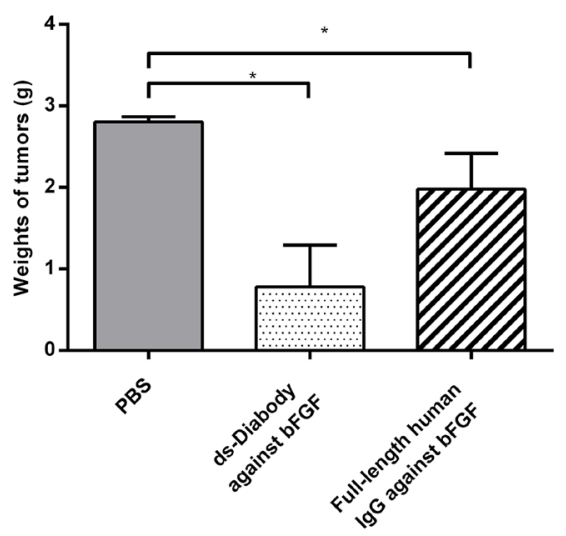

b

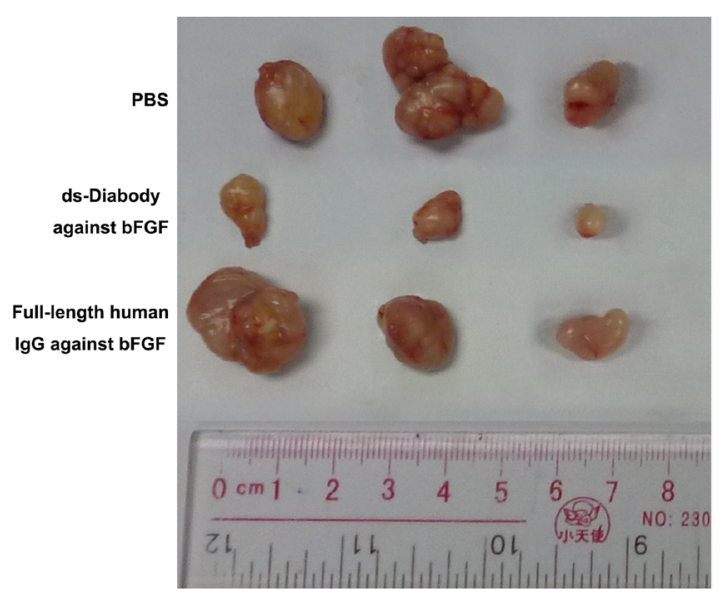

d

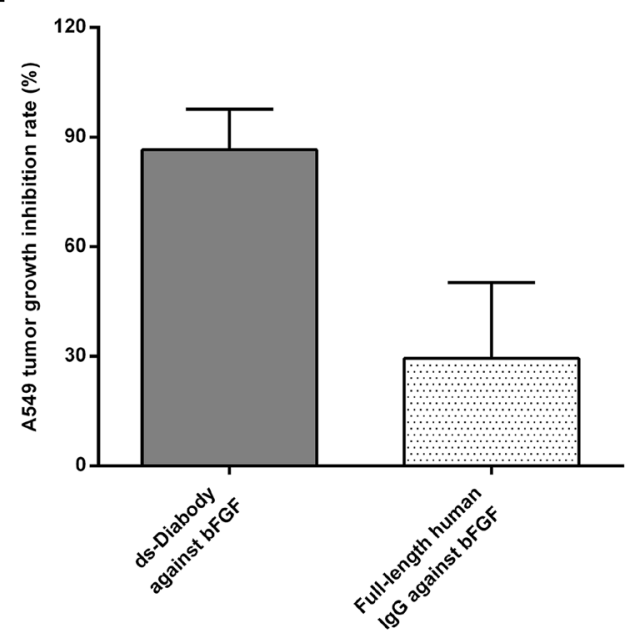

Figure 8: The inhibition of tumor growth by the ds-Diabody against bFGF in mice model. The lung cancer cells (A549, $1 \times 10^{6}$ cells) were injected in the shoulders of $\mathrm{BALB} / \mathrm{c}$ nude mice $(\mathrm{n}=6)$. After the tumor palpable, the mice were intravenously injected with the dsDiabody against bFGF $(10 \mathrm{mg} / \mathrm{kg})$ six times with 3 days interval and the tumor volume was measured at different time-points after treatment. a. Tumor growth curve in different groups. b. Stripped tumors in different groups. c. Quantitative analysis of the tumor weight. d. The growth inhibition rate of tumors in different groups. The data were represented as the means $\pm \mathrm{SD}$ (error bars) from 6 animals. ${ }^{*} \mathrm{P}<0.05 ;{ }^{*} * \mathrm{P}<0.01$. 
cells may be chemo-attracted by the serum in the lower chamber and result in invasion. The invasion ratio of A549 cells in the group of ds-Diabody against bFGF was about $31.56 \%$ while the negative control group was $78.65 \%$. The results indicated that the ds-Diabody against bFGF could significantly inhibit the invasion of A549 cells (Figure 7).

\section{Tumor growth inhibition of the ds-Diabody against bFGF in mice model}

In order to investigate the inhibitive effect of the ds-Diabody against bFGF on A549 cells growth in vivo, a xenograft tumor model of lung cancer was established in $\mathrm{BALB} / \mathrm{c}$ nude mice. The results indicated that the administration of the ds-Diabody against bFGF could significantly inhibit the tumor growth in the tumor-bearing mice (Figure 8a-8c). Compared with the negative control group, the inhibition rate of tumor growth in the group of ds-Diabody against bFGF could reach $86.54 \%$, while the group of the full-length human IgG against bFGF was about $29.46 \%$ (Figure $8 d$ ).

\section{Inhibition of tumor angiogenesis and lymphangiogenesis in vivo by the ds-Diabody against bFGF}

The tumor angiogenesis and lymphangiogenesis were assessed by immunohistochemical staining with antiCD31 and anti-LYVE1 antibodies. The average number of microvessels was about 41.0 in the group of the dsDiabody against bFGF and 63.0 in the group of PBS. The average number of lymphatic vessels was about 4.0 in the group of the ds-Diabody against bFGF and 13.0 in the group of PBS (Figure 9). The results demonstrated that the ds-Diabody against bFGF could significantly suppress angiogenesis and lymphangiogenesis in tumor tissue.
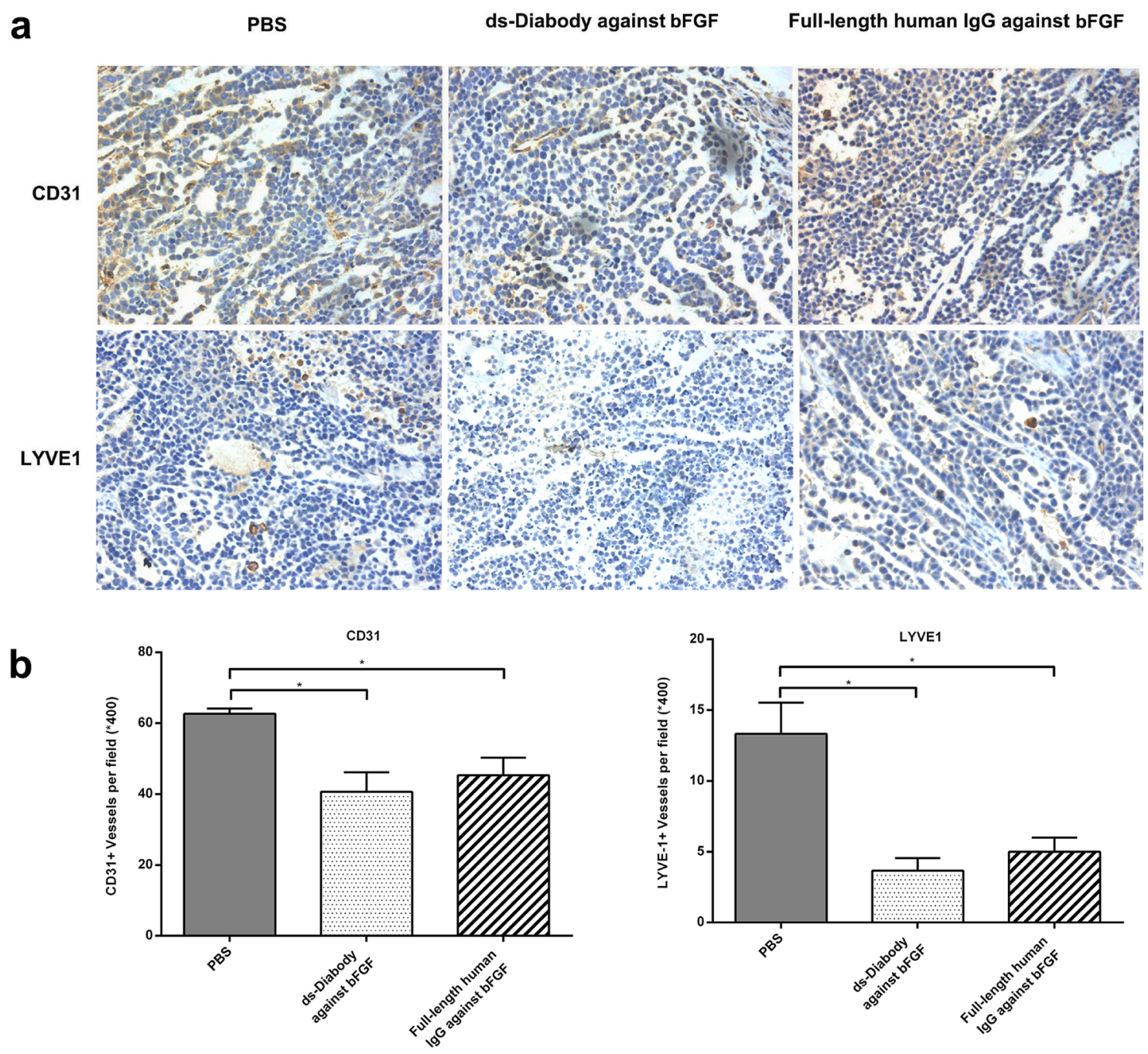

Figure 9: Immunohistochemical analyses of tumor tissues. a. Paraffin sections of A549 tumors were stained for vascular endothelial cells with anti-CD31 antibody and lymphatic endothelial cells with anti-LYVE1 antibody respectively. b. Quantitative analysis of microvessel density and lymphatic vessels density. The number of blood vessels and lymphatic vessels at 5 high-power fields (x400) per section were counted. The data were represented as the means $\pm \mathrm{SD}$ (error bars). ${ }^{*} \mathrm{P}<0.05 ; * * \mathrm{P}<0.01$. 


\section{DISCUSSION}

In our previous study, high affinity human antibodies of scFv against bFGF were selected from a phage display library, and the full-length human antibody against bFGF was reconstructed [16]. The full-length human antibody against bFGF could significantly inhibit the growth of melanoma [16]. Diabody is one of the smallest of bivalent antibody with approximately one-third the molecular weight of full-length antibody molecules, which may improve its penetration into tumor tissue [17]. In order to increase the stability of the Diabody, we constructed a human disulfide-stabilized Diabody against bFGF by introducing the disulphide bonds between the $\mathrm{VH}$ and $\mathrm{VL}$ domain by site directed mutation. The result of indirect ELISA indicated that the introducing of disulphide bonds in the variable region of diabody did not affect its antigen binding activity.

In this study, the ds-Diabody against bFGF could significantly suppress the tumor growth in nude mice and the inhibition rate could reach about $86.54 \%$. Compared with the full-length human antibody against bFGF, the ds-Diabody against bFGF showed a stronger inhibitory effect on the growth of tumor, possibly because the dsDiabody agasint bFGF has a stronger penetration with low molecular weight.

The signaling pathways of MAPK/ERK and PI3K/AKT are the main pathways that involved in the proliferation, migration and invasion of tumor cell [24]. Blockade of MAPK/ERK signaling pathway by antibFGF antibody could result in suppressing of invasion and migration triggered by bFGF [25]. We found that the ds-Diabody against bFGF could effectively inhibit the proliferation, migration and invasion of the A549 cells by blocking the signal pathway of Akt and MAPK.

In this study, we have preliminarily explored the inhibitory effect of the human ds-diabody against bFGF on the growth of A549 cells in vitro and in vivo. The results indicated that the ds-Diabody could effectively neutralize the paracrine and autocrine bFGF in tumors and block the signaling pathways of MAPK/ERK and PI3K/AKT and inhibit the tumor angiogenesis and lymphangiogenesis.

\section{MATERIALS AND METHODS}

\section{Cells and animals}

Human lung cancer cells (A549) were cultured in Dulbecco's modified Eagle's medium (DMEM) plus 10\% FBS and $1 \%$ penicillin/streptomycin. All the cells were cultured in an incubator with $95 \%$ humidity and $5 \% \mathrm{CO}_{2}$ at $37^{\circ} \mathrm{C}$.

BALB/c nude mice (female, 6-8 weeks) were purchased from Laboratory Animal Center of Sun Yat-Sen University, Guangzhou, China. All the animals used in the experiments were treated humanely in accordance with
Institutional Animal Care and Use Committee guidelines in Jinan University.

\section{Expression and purification of the ds-Diabody against bFGF}

In our previous study, high affinity human antibodies of $\mathrm{scFv}$ against bFGF were selected from a phage display library [16]. The ds-Diabody against bFGF was constructed by site-directed mutation and overlap extension (SOE-PCR) at the position of VH44 and VL100 in the scFv. Tao has prepared a full-length human antibody against bFGF which was used as a positive control in our study [16].

The recombinant plasmid pPICZaA-ds-Diabody was transformed into Pichia pasporis strain GS115. The ds-Diabody against bFGF was obtained by the induction culture of the recombinant yeast transformants. The dsDiabody against bFGF was purified from the expression supernatant by affinity chromatography and anionexchange chromatography [26]. The target protein was assayed by SDS-PAGE and western-blot.

\section{Antigen binding activity of the ds-Diabody against bFGF}

The 96-well plates were coated with bFGF (50 ng/ well, R\&D Systems) at $4^{\circ} \mathrm{C}$ overnight and blocked with $5 \%$ non-fat milk. The purified ds-Diabody against bFGF was diluted serially and added into the 96-well plates and incubated for $1 \mathrm{~h}$ at $37^{\circ} \mathrm{C}$. The plates were washed 3 times with PBST (25 mM sodium phosphate, $\mathrm{pH} 7.4$, $150 \mathrm{mM} \mathrm{NaCl}$ and $0.05 \%$ Tween-20) and the anti-His tag monoclonal antibody (1: 5000 dilution) was added and incubated for $1 \mathrm{~h}$ at $37^{\circ} \mathrm{C}$. After washing, HRP-conjugated goat anti-mouse $\operatorname{IgG}$ was added and incubated for $30 \mathrm{~min}$ at $37^{\circ} \mathrm{C}$. The plates were then stained with DAB (Sigma) and the absorbance values at $450 \mathrm{~nm}\left(\mathrm{~A}_{450}\right)$ values were immediately measured in an ELISA reader.

\section{Cell proliferation assay}

A549 cells were transferred in 96-well plates at a density of 2000 cells/well and incubated overnight at $37^{\circ} \mathrm{C}$ in a $5 \% \mathrm{CO}_{2}$ incubator. After starved cultivation in DMEM with $0.5 \%$ FBS for $12 \mathrm{~h}$, cells were treated with serially diluted ds-Diabody against bFGF (6.25-100 $\mu \mathrm{g} /$ $\mathrm{mL}$ ), together with $15 \mathrm{ng} / \mathrm{mL} \mathrm{bFGF}$ for $48 \mathrm{~h}$. The control groups were treated with the full-length human IgG against bFGF or the irrelevant IgG. The number of viable cells was finally determined by Cell Counting kit- 8 (CCK8) reagent. According to the manufacturer's protocol, 10 $\mu$ L CCK-8 was quickly added to each well and incubated with cells for $2 \mathrm{~h}$. After incubation, the absorbance at 450 $\mathrm{nm}$ was immediately measured in an ELISA reader. The cell proliferation inhibition rate was calculated. 


\section{Western blot assay}

The A549 cells $\left(2 \times 10^{5}\right.$ cells/well $)$ were transferred in 6-well plates and serum-starved cultured in DMEM with $0.5 \%$ FBS overnight. The cells were exchanged with the medium of DMEM with $15 \mathrm{ng} / \mathrm{mL}$ bFGF and $0.5 \%$ FBS and serially concentrations of the ds-Diabody and incubated for $30 \mathrm{~min}$. The cells were washed with cold PBS and lysed in RIPA buffer. The lysates were centrifuged at $12000 \mathrm{~g}$ for $6 \mathrm{~min}$ at $4^{\circ} \mathrm{C}$ and the total proteins in the supernatant were quantified by BCA Protein Assay Kit (Thermo). The proteins were separated by SDS-PAGE and transferred to PVDF membrane (Millipore). The membrane was blocked with 5\% nonfat milk at $37^{\circ} \mathrm{C}$ for $1 \mathrm{~h}$. After washing 3 times with PBST, phosphorylation of MAPK and Akt were detected by rabbit anti p-MAPK (cell signaling \#4370) and rabbit anti p-Akt (cell signaling \#4060) antibodies, respectively. Total MAPK and Akt were detected by rabbit anti-MAPK (cell signaling \#4695) and rabbit anti-Akt (cell signaling \#4691) antibodies, respectively. The membrane was incubated with the primary antibody at $4^{\circ} \mathrm{C}$ overnight. After washing, the membrane was then incubated with the HRP-conjugated goat anti-rabbit $\operatorname{IgG}$ for $1 \mathrm{~h}$ at $37^{\circ} \mathrm{C}$. The blots were then detected with an ECL detection kit (Millipore) according to the manufacturer's protocol. The anti- $\beta$-actin antibody (cell signaling, \#4970) was used as the reference control.

\section{Scratch assay}

The effect of the ds-Diabody against bFGF on migration of A549 cells was evaluated by scratch assay. A549 cells $\left(5 \times 10^{5}\right.$ cells/well $)$ suspended in DMEM complete medium were transferred in 6-well plates. After incubated for $24 \mathrm{~h}$, a scratch treatment was taken. After washing with serum-free DMEM, the DMEM with $0.5 \%$ FBS and ds-Diabody against bFGF $(100 \mu \mathrm{g} /$ $\mathrm{mL}$ ) was added to the wells. The controls were the fulllength human IgG against bFGF $(100 \mu \mathrm{g} / \mathrm{mL})$ and the irrelevant $\operatorname{IgG}(100 \mu \mathrm{g} / \mathrm{mL})$ and the medium only. After incubated for 0,12 and $24 \mathrm{~h}$, the plates were imaged with a computerized imaging system. The cell migration rate of each group was calculated.

\section{Invasion assay}

The effect of the ds-Diabody against bFGF on invasion of A549 cells was assayed in transwell chambers. The upper side of the filters was coated with $45 \mu \mathrm{l}$ matrigel matrix (BD) diluted (1:3) with serum-free DMEM. After serum-starved for $12 \mathrm{~h}$, A549 cells were seeded $\left(5 \times 10^{4}\right.$ cells/well) onto the layer of Matrigel using serum-free medium, then stimulated with $15 \mathrm{ng} / \mathrm{mL}$ bFGF and $100 \mu \mathrm{g} /$ $\mathrm{mL}$ ds-Diabody against $\mathrm{bFGF}$ for $16 \mathrm{~h}$. The control groups were the full-length human IgG against bFGF $(100 \mu \mathrm{g} /$ $\mathrm{mL})$, the irrelevant $\operatorname{IgG}(100 \mu \mathrm{g} / \mathrm{mL})$ and the medium only.
The lower chambers were DMEM with $10 \%$ FBS. At the end of the treatment, cells on the upper side of the filters were mechanically removed, and those migrated onto the lower side were fixed with $70 \%$ ethanol, stained by $0.1 \%$ crystal violet (Meryer) and imaged with a computerized imaging system.

\section{Tumor model}

Human lung cancer A549 cells $\left(1 \times 10^{6}\right.$ cells in 100 $\mu 1)$ were subcutaneously injected into the right shoulder flank of BALB/c nude mice (15-20 g, $\mathrm{n}=6)$. When palpable tumors ( $\geq 5 \mathrm{~mm}$ in diameter) developed, the tumor-bearing mice were intravenously injected with $10 \mathrm{mg} / \mathrm{kg}$ ds-Diabody against bFGF or the full-length human antibody against bFGF or PBS six times at 3 days intervals. Tumor size was measured every 3 days in two dimensions using a vernier caliper. Mice were euthanized 24 hours later after the last administration. The tumors were stripped for immunohistochemistry and weighed to calculate the tumor growth inhibition rate. Tumor volume $\left(\mathrm{mm}^{3}\right)$ was calculated as $\mathrm{V}=1 / 2(\mathrm{a}$ $\times b^{2}$ ). $a=$ tumor length, $b=$ tumor width; Tumor growth inhibition rate $=(1-$ the average tumor weight of treated groups / the average tumor weight of PBS group) $\times$ $100 \%$.

\section{Evaluation of microvessel density and lymphatic vessels density in subcutaneous tumors}

Tumor tissues were fixed in $4 \%$ paraformaldehyde, embedded in paraffin, and cut at $5 \mu \mathrm{m}$. After deparaffinization, the sections were heat for $10 \mathrm{~min}$ at $100^{\circ} \mathrm{C}$ in sodium citrate buffer $(10 \mathrm{mM}, \mathrm{pH} 6.0)$ for antigen retrieval and treated with $3 \% \mathrm{H}_{2} \mathrm{O}_{2}$ for $15 \mathrm{~min}$ at room temperature to block endogenous peroxidase activity. The sections were blocked in 3\% bovine serum albumin (BSA) for $1 \mathrm{~h}$ and incubated with primary antibodies overnight at $4^{\circ} \mathrm{C}$ (rabbit anti-CD31 polyclonal antibodies and rabbit Anti-LYVE1 polyclonal antibody, Abcam). The sections were then incubated with secondary antibody of biotinylated goat anti-rabbit polyclonal antibody and avidin-HRP for $1 \mathrm{~h}$. The sections were stained with 3, 3'-diaminobenzidine (DAB) and hematoxylin. The vessels density was determined by counting the number of microvessels and lymphatic vessels in five random high-power fields within the sections, as described [12].

\section{Statistics analysis}

Statistical comparisons were analyzed by oneway analysis of variance (ANOVA) followed by the least significant difference (LSD) test. The data were represented as mean $\pm \mathrm{SD}$. $P$-values $<0.05\left(^{*}\right)$ and $P<$ $0.01(* *)$ were considered statistically significant. 


\section{ACKNOWLEDGMENTS}

This work was supported by grants from the State Natural Science Foundation of China (No.81372281), the Science and Technology Planning Project of Guangdong Province (No.2015B020211009, No.2016A010105008) and the Science and Technology Planning Project of Guangzhou City (No.201604020099).

\section{CONFLICTS OF INTEREST}

No potential conflicts of interest were disclosed.

\section{REFERENCES}

1. Wesche J, Haglund K, Haugsten EM. Fibroblast growth factors and their receptors in cancer. Biochem J. 2011; 437:199-213.

2. Zhang Q, Lao X, Huang J, Zhu Z, Pang L, Tang Y, Song Q, Huang J, Deng J, Deng N. Soluble production and function of vascular endothelial growth factor/basic fibroblast growth factor complex peptide. Biotechnology progress. 2015; 31:194-203.

3. Presta M, Dell'Era P, Mitola S, Moroni E, Ronca R, Rusnati M. Fibroblast growth factor/fibroblast growth factor receptor system in angiogenesis. Cytokine \& Growth Factor Reviews. 2005; 16:159-78.

4. Bikfalvi A, Klein S, Pintucci G, Rifkin DB. Biological roles of fibroblast growth factor-2. Endocrine reviews. 1997; 18:26-45.

5. Eswarakumar VP, Lax I, Schlessinger J. Cellular signaling by fibroblast growth factor receptors. Cytokine \& Growth Factor Reviews. 2005; 16:139-49.

6. Ito H, Oshita F, Kameda Y, Suzuki R, Ikehara M, Arai H, Mitsuda A, Saito H, Yamada K, Noda K, Nakayama $\mathrm{H}$. Expression of vascular endothelial growth factor and basic fibroblast growth factor in small adenocarcinomas. Oncology Reports. 2002; 9:119-23.

7. Volm M, Koomagi R, Mattern J. PD-ECGF, bFGF, and VEGF expression in non-small cell lung carcinomas and their association with lymph node metastasis. Anticancer research. 1999; 19:651-5.

8. Matsuzaki K, Yoshitake Y, Matuo Y, Sasaki H, Nishikawa K. Monoclonal antibodies against heparin-binding growth factor II/basic fibroblast growth factor that block its biological activity: invalidity of the antibodies for tumor angiogenesis. Proceedings of the National Academy of Sciences of the United States of America. 1989; 86:9911-5.

9. Coppola G, Atlas-White M, Katsahambas S, Bertolini J, Hearn MT, Underwood JR. Effect of intraperitoneally, intravenously and intralesionally administered monoclonal anti-beta-FGF antibodies on rat chondrosarcoma tumor vascularization and growth. Anticancer research. 1997; 17:2033-9.
10. Nemati MN, Stan AC, Putz KM, Pietsch T, Walter GF, Dietz $\mathrm{H}$. Inhibition of angiogenesis and growth of malignant gliomas in the athymic nude rat model: immunotherapy against "basic fibroblast growth factor". [Article in German]. Zentralblatt fur Neurochirurgie. 1996; 57:12-9.

11. Pan L, Weng R, Zhang J, Wang J, Tang Y, Deng N. Immune Response of the VEGF/bFGF Complex Peptide Vaccine and Function of Immune Antibodies in Inhibiting Migration of HUVEC Cells and Proliferation of Cancer Cells. International Journal of Peptide Research and Therapeutics. 2014; 20:565-74.

12. Li D, Wang H, Xiang JJ, Deng N, Wang PP, Kang YL, Tao $\mathrm{J}, \mathrm{Xu} \mathrm{M}$. Monoclonal antibodies targeting basic fibroblast growth factor inhibit the growth of B16 melanoma in vivo and in vitro. Oncology Reports. 2010; 24:457-63.

13. Crombet $\mathrm{T}$, Torres $\mathrm{O}$, Rodriguez V, Menendez A, Stevenson A, Ramos M, Torres F, Figueredo R, Veitia I, Iznaga N, Perez R, Lage A. Phase I clinical evaluation of a neutralizing monoclonal antibody against epidermal growth factor receptor in advanced brain tumor patients: Preliminary study. Hybridoma. 2001; 20:131-6.

14. Gordon AN, Schultes BC, Gallion H, Edwards R, Whiteside TL, Cermak JM, Nicodemus CF. CA125-and tumorspecific T-cell responses correlate with prolonged survival in oregovornab-treated recurrent ovarian cancer patients. Gynecologic Oncology. 2004; 94:340-51.

15. Cheung NKV, Guo H, Hu J, Tassev DV, Cheung IY. Humanizing murine IgG3 anti-GD2 antibody m3F8 substantially improves antibody-dependent cellmediated cytotoxicity while retaining targeting in vivo. Oncoimmunology. 2012; 1.

16. Tao J, Xiang JJ, Li D, Deng N, Wang H, Gong YP. Selection and characterization of a human neutralizing antibody to human fibroblast growth factor-2. Biochemical and Biophysical Research Communications. 2010; 394:767-73.

17. Reiter Y, Brinkmann U, Webber KO, Jung SH, Lee B, Pastan I. Engineering interchain disulfide bonds into conserved framework regions of Fv fragments: improved biochemical characteristics of recombinant immunotoxins containing disulfide-stabilized Fv. Protein engineering. 1994; 7:697-704.

18. Holliger P, Prospero T, Winter G. "Diabodies": small bivalent and bispecific antibody fragments. Proceedings of the National Academy of Sciences of the United States of America. 1993; 90:6444-8.

19. Reiter Y, Brinkmann U, Jung SH, Lee B, Kasprzyk PG, King CR, Pastan I. Improved binding and antitumor activity of a recombinant anti-erbB2 immunotoxin by disulfide stabilization of the Fv fragment. The Journal of biological chemistry. 1994; 269:18327-31.

20. Brinkmann U, Reiter Y, Jung SH, Lee B, Pastan I. A recombinant immunotoxin containing a disulfide-stabilized Fv fragment. Proceedings of the National Academy of Sciences of the United States of America. 1993; 90:7538-42. 
21. Rodrigues ML, Presta LG, Kotts CE, Wirth C, Mordenti J, Osaka G, Wong WL, Nuijens A, Blackburn B, Carter P. Development of a humanized disulfide-stabilized antip185HER2 Fv-beta-lactamase fusion protein for activation of a cephalosporin doxorubicin prodrug. Cancer research. 1995; 55:63-70

22. Li W, Fan D, Yang M, Shi R, Yan Y, Jiang L, Yan C, Li S, Wang M, Wang J, Xiong D. Disulfide-stabilized diabody antiCD19/antiCD3 exceeds its parental antibody in tumortargeting activity. Cellular Oncology. 2012; 35:423-34.

23. Song L, Li D, Gu Y, Wen ZM, Jie J, Zhao D, Peng LP. MicroRNA-126 Targeting PIK3R2 Inhibits NSCLC A549 Cell Proliferation, Migration, and Invasion by Regulation of PTEN/PI3K/AKT Pathway. Clinical lung cancer. 2016.
24. Zhou HL, Li XM, Meinkoth J, Pittman RN. Akt regulates cell survival and apoptosis at a postmitochondrial level. Journal of Cell Biology. 2000; 151:483-94.

25. Suyama K, Shapiro I, Guttman M, Hazan RB. A signaling pathway leading to metastasis is controlled by N-cadherin and the FGF receptor. Cancer Cell. 2002; 2:301-14.

26. Klenotic PA, Page RC, Misra S, Silverstein RL. Expression, purification and structural characterization of functionally replete thrombospondin-1 type 1 repeats in a bacterial expression system. Protein Expression and Purification. 2011; 80:253-9. 